UDK 528.92

\title{
DATA STYLING IN WEB MAPPING APPLICATIONS WITH A FOCUS ON ENVIRONMENTAL HEALTH
}

\author{
Tatiana HARCINÍKOVÁ ${ }^{1}$, Alexandra BENOVÁ ${ }^{2}$, Richard FECISKANIN ${ }^{3}$, Radoslav CHUDÝ ${ }^{4}$, \\ Miroslav KOŽUCH ${ }^{5}$, Vladimír PELECH ${ }^{6}$, Tomáš SCHMIDT ${ }^{7}$, Hana STANKOVÁ ${ }^{8}$, \\ Juraj VALIŠ ${ }^{9}$, Eva MIČIETOVÁ 10 \\ 1, 2, 3, 5, 6, 7, 8, 9, ${ }^{10}$ Department of Cartography, Geoinformatics and Remote Sensing, \\ Faculty of Natural Sciences, Comenius University in Bratislava, Slovakia, \\ Mlynská dolina, Ilkovičova 6, 84215 Bratislava, Slovakia \\ 1, 2, 3, 4, 5, 6, 7, 8, 9, ${ }^{10}$ Comenius University Science Park, Ilkovičova 8, 84104 Bratislava, Slovakia \\ E-mails: ${ }^{1}$ harcinikova@fns.uniba.sk (corresponding author); ${ }^{2}$ benova@fns.uniba.sk; \\ 3feciskanin@fns.uniba.sk; ${ }^{4}$ chudy@fns.uniba.sk; ${ }^{5}$ kozuch@fns.uniba.sk; ${ }^{6}$ pelechv@fns.uniba.sk; \\ ${ }^{7}$ stankova@fns.uniba.sk; ${ }^{8}$ schmidt@fns.uniba.sk; ${ }^{9}$ valis@fns.uniba.sk; ${ }^{10}$ micietova@fns.uniba.sk
}

\section{Received 9 March 2017; accepted 27 November 2017}

\begin{abstract}
Interpretation of data visualized in maps strongly depends on the experience of map reader and on the way the data are presented. Styling the data is crucial especially when creating maps for users with weaker cartographic knowledge and map reading experience. Because web mapping applications make spatial data more accessible to general public, this issue requires special attention in terms of their design. Here we present a styling approach for designing a web mapping application that assembles huge amount of data related to the issue of environmental health, based on our own experience with creating a web mapping application available at https://uvp.geonika.sk/map/ (Department of Cartography... 2016). As the field of environmental health is multidisciplinary, it requires combination of data from various sources and of various types, topics and resolutions. Various data were compiled, requiring thoughtful approach to styling with regard to the users of the mapping application, who are supposed to be not only professionals (from the field of geography and geoinformatics as well as of medicine, epidemiology, environmental sciences etc.), but also general public. Many of such users do not possess adequate cartographic knowledge, which is the reason why the data styling had to reflect this limitation.
\end{abstract}

Keywords: web mapping application, environmental health, map styling, colour schemes, map syntactic types, SLD.

\section{Introduction}

Presentation of spatial data using web mapping applications (WMAs) is rapidly increasing. Avraam (2009) defines WMAs as applications that enable visualization of geographically referenced data through a web interface available online. In general, visualization of spatial data (referred to as cartographic visualization, geographic visualization or geovisualization, with only slight differences in meaning (Hallisey 2005)) is not a simple and straightforward process. It requires adequate attention and consideration of several factors, such as purpose of the visualization, who the audience is, type of data, level of user interaction, etc. The ability to understand map visualization of data is sometimes referred to as graphicacy, an ability at the level of literacy, numeracy, and articulacy, complementing these three (Hallisey 2005). Analogically, people possess different levels of graphicacy, which can be improved by training. Thus, general public probably have, in general, less developed graphicacy than professionals in cartography or geography, which needs to be addressed by the professional mapmakers.

Over the last decades, mapping (environmental) health data has become increasingly popular and common with the advances in information technologies and availability of GIS and mapping software. Recently, due to a rapid development and increase in availability of the Internet, the cartographic data presentation relocated in a significant degree to online environment. Online mapping data presentations become ubiquitous 
also due to the increasing availability of open and big data (Smith 2016) and tools approachable also for GIS non-specialists (Zastrow 2015).

The major advantage of online mapping is its interactivity, bringing many opportunities (and challenges, too) for data visualization and map styling. Roth (2013) defines cartographic interaction as "the dialogue between a human and a map mediated through a computing device to emphasize digital interaction", thus accentuating the two-way communication. Currently, the major function of online interactive mapping tools is a mixture of data presentation and exploration, in some cases (mostly in research fields of geodemographics, health geography, and urban analytics) including at least basic analytical possibilities (Smith 2016).

Importantly, communicating sensitive health data using maps requires especially careful approach; the representation needs to be accurate, clear, and not misleading for various types of viewers, and several factors needs to be addressed, including limitations and quality of data, data confidentiality, uncertainty of estimates, and risk of misinterpreting (Bell et al. 2006). These issues can be approached, among other, by selecting the appropriate method of map representation and data styling as one of the aspects of building a WMA.

In this paper, we present and analyse various approaches to data styling in interactive WMAs visualizing environmental health data building on a theory of map representation methods and map syntactic types by Pravda $(2003,2006)$ and Pravda and Kusendová (2007). Map syntactic types encapsulate principles of map sign composition and are defined based on one or more typifying criteria. With subtypes, variants, and subvariants, this approach to classification of map representation methods has hierarchical character and is open to new criteria and types.

Following a cartographic visualization analysis of 21 web environmental health mapping solutions with focus on data styling, we subsequently describe our approach to data styling using OGC standards in our WMA. This application gathers environmental and health data from various sources and aims to facilitate understanding of their spatial patterns and interactions. Collecting such amount of data, the main aim of the paper is to present the approach to their styling in a way that is user-friendly and interpretable to both researchers and general public, though still cartographically correct.

\section{Review of WMAs with environmental health focus}

There are many different WMAs available in the environment of world wide web with different topics, designs, and cartographic visualizations. In our analysis, we focused on WMAs communicating themes of environmental health, environmental risks and hazards.

We analysed 21 WMAs (Table 1), 13 of them operating under the head of the World Health Organization (WHO) and dealing with the issues of environmental health and health indicators, three developed under the head of the United Nations Office for Disaster Risk Reduction (UNISDR) and dealing with environmental threats and risks, three being a part of Eurostat, which accumulate different statistical data, e.g. about health or population. The last two applications are Slovak WMAs showing data from the domain of environmental indicators and health for the area of Slovakia. The WMAs were selected predominantly by thematic criteria: the search terms included combinations of keywords health, environment, risk and hazard.

The WMAs were analysed from several viewpoints of data styling, including map syntactic types, data intervals, colour schemes and data series. Overall, we used the following 11 criteria labelled A to K (Table 2):

- A - type of presented data - qualitative or quantitative,

- B - map syntactic types (Pravda 2002):

$-\mathrm{S}_{\mathrm{F}}(\mathrm{Q}$, Top) - type of qualitative figural signs with topographical location,

- $S_{L}(Q)$ - type of qualitative linear signs,

- $S_{A D}(Q)$ - type of qualitative discrete areas,

$-S_{A D}(M, I n t)$ - type of quantitative discrete areas (choropleth type),

$-S_{F}(M$, Diagr $)$ - type of quantitative diagrammatic sign,

- $S_{L}(M$, Diagr $)$ - type of quantitative linear diagrammatic sign,

- $\mathrm{S}_{\mathrm{AC}}(\mathrm{M}$, Isogr $)$ - type of quantitative continuous (isogradational) areas,

- C - spatial extent and level of detail,

- D - type of data scale - intervals, intervals with limit values, continuous, categories,

- E - possibility of data scale change - yes/no,

- F - data series - yes/no,

- G - colour schemes - 1 colour scheme, sequence of multiple colours, different colours,

- H - possibility of colour scheme change - yes/no, - I - change in colour scheme - individual colours, default schemes, default schemes in Brewer colours (Brewer 2014), no change possible, 
Table 1. List of the analysed web mapping applications

\begin{tabular}{|c|c|c|}
\hline No. & Provider & Title \& Link \\
\hline 1 & $\begin{array}{l}\text { WHO and UNICEF - Joint Monitoring Programme } \\
\text { for Water Supply and Sanitation }\end{array}$ & Data and estimates \\
\hline 2 & WHO - Regional Office for the Americas & $\begin{array}{l}\text { Pandemic (H1N1) } 2009 \text { - Human Deaths by Country in the } \\
\text { Americas }\end{array}$ \\
\hline 3 & WHO - Regional Office for the Americas & $\begin{array}{l}\text { Regional Update on Acute Respiratory Disease: Qualitative } \\
\text { Indicators by Epidemiological week 2009-2010 }\end{array}$ \\
\hline 4 & $\begin{array}{l}\text { WHO - Regional Office for the Eastern } \\
\text { Mediterranean }\end{array}$ & Regional Health Observatory - InstantAtlas Dynamic Report \\
\hline 5 & WHO - Western Pacific Region & Health Information and Intelligence Platform \\
\hline 6 & WHO - Regional Office for Europe & Equity in health project - Correlation map atlas \\
\hline 7 & WHO - Regional Office for Europe & Equity in health project - Atlases of social inequalities \\
\hline 8 & WHO - Regional Office for Europe & Equity in health project - Regional comparison atlas \\
\hline 9 & WHO - Regional Office for Europe & Atlases of core health indicators \\
\hline 10 & WHO - Regional Office for Europe & Atlases of burden of disease \\
\hline 11 & $\begin{array}{l}\text { WHO and UNICEF - Group for Child Mortality } \\
\text { Estimation }\end{array}$ & Child Mortality Estimates (CME) \\
\hline 12 & WHO - Regional Office for Europe & Atlas of Millennium Development Goals (MDGs) indicators \\
\hline 13 & WHO - Regional Office for Europe & Environment and Health Information System (ENHIS) \\
\hline 14 & $\begin{array}{l}\text { The United Nations Office for Disaster Risk } \\
\text { Reduction (UNISDR) }\end{array}$ & Global Assessment Report on Disaster Risk Reduction 2015 \\
\hline 15 & UNEP/GRID-Geneva and UNISDR & Global Risk Data Platform \\
\hline 16 & UNISDR & DesInventar as a Disaster Information Management System \\
\hline 17 & Eurostat & Regional Statistics Illustrated \\
\hline 18 & Eurostat & Country Profiles \\
\hline 19 & Eurostat & Statistical Atlas - Eurostat regional yearbook 2016 \\
\hline 20 & Ministry of the Environment of the Slovak Republic & $\begin{array}{l}\text { Informačný systém environmentálne zátaže [Information system of } \\
\text { environmental burdens] }\end{array}$ \\
\hline 21 & State Geological Institute of Dionýz Štúr & $\begin{array}{l}\text { Environmentálne a zdravotné indikátory Slovenskej republiky } \\
\text { [Environmental and health indicators of the Slovak Republic] }\end{array}$ \\
\hline
\end{tabular}

Table 2. Mutual comparison of the analysed WMAs from the viewpoint of theory of map representation methods

\begin{tabular}{|c|c|c|c|c|c|c|c|c|c|c|c|}
\hline No & A & B & $\mathrm{C}$ & $\mathrm{D}$ & $\mathrm{E}$ & $\mathrm{F}$ & G & $\mathrm{H}$ & I & $\mathrm{J}$ & K \\
\hline 1 & M & $\mathrm{S}_{\mathrm{AD}}(\mathrm{M}, \mathrm{Int})$ & $\begin{array}{l}\text { States of world, regions, } \\
\text { individual states }\end{array}$ & I & $\mathrm{N}$ & Y & $\mathrm{D}, 1-\mathrm{C}, \mathrm{n}-\mathrm{C}$ & Y & Ic & $\mathrm{Cw}$ & $\mathrm{N}$ \\
\hline 2 & M & $\mathrm{S}_{\mathrm{AD}}(\mathrm{M}$, Int $)$ & States of world & I & $\mathrm{Y}$ & $\mathrm{Y}$ & $1-C, n-C$ & Y & Ds-BC & $\mathrm{Cc}$ & $\mathrm{Y}$ \\
\hline 3 & Q & $\mathrm{S}_{\mathrm{AD}}(\mathrm{Q})$ & States of world & $\mathrm{K}$ & $\mathrm{N}$ & Y & $1-C, n-C$ & $\mathrm{~N}$ & - & $\mathrm{Cc}$ & $\mathrm{Y}$ \\
\hline 4 & M & $\mathrm{S}_{\mathrm{AD}}(\mathrm{M}, \mathrm{Int})$ & States of region & I & Y & Y & $1-C, n-C$ & Y & Ds-BC & $\mathrm{Cc}$ & $\mathrm{Y}$ \\
\hline 5 & M & $\mathrm{S}_{\mathrm{AD}}(\mathrm{M}, \mathrm{Int})$ & States of region & I & Y & Y & $1-C, n-C$ & Y & Ds & $\mathrm{Cc}$ & $\mathrm{N}$ \\
\hline 6 & M & $\mathrm{S}_{\mathrm{AD}}(\mathrm{M}, \mathrm{Int})$ & States of region & I & Y & $\mathrm{N}$ & $1-C, n-C$ & Y & Ds-BC & $\mathrm{Cc}$ & $\mathrm{N}$ \\
\hline 7 & M, Q & $\mathrm{S}_{\mathrm{AD}}(\mathrm{M}$, Int $)$ & NUTS & I & Y & $\mathrm{N}$ & $1-C, n-C$ & Y & Ds-BC & $\mathrm{Cc}$ & $\mathrm{N}$ \\
\hline 8 & M & $\mathrm{S}_{\mathrm{AD}}(\mathrm{M}$, Int $)$ & NUTS & I & Y & $\mathrm{N}$ & $1-C, n-C$ & Y & Ds-BC & $\mathrm{Cc}$ & $\mathrm{N}$ \\
\hline 9 & M & $\mathrm{S}_{\mathrm{AD}}(\mathrm{M}$, Int $)$ & States of region & I & Y & Y & $1-C, n-C$ & Y & Ds-BC & $\mathrm{Cw}$ & $\mathrm{N}$ \\
\hline 10 & M & $\mathrm{S}_{\mathrm{AD}}(\mathrm{M}$, Int $)$ & States of region & I & Y & $\mathrm{N}$ & $1-C, n-C$ & Y & Ds-BC & $\mathrm{Cw}$ & $\mathrm{N}$ \\
\hline 11 & M & $\mathrm{S}_{\mathrm{AD}}(\mathrm{M}, \mathrm{Int})$ & States of world & I & $\mathrm{N}$ & $\mathrm{Y}$ & $\mathrm{D}$ & $\mathrm{N}$ & - & $\mathrm{Cc}$ & $\mathrm{N}$ \\
\hline
\end{tabular}


End of Table 2

\begin{tabular}{|c|c|c|c|c|c|c|c|c|c|c|c|}
\hline No & $\mathrm{A}$ & B & $\mathrm{C}$ & $\mathrm{D}$ & E & $\mathrm{F}$ & G & $\mathrm{H}$ & I & $J$ & K \\
\hline 12 & M & $\mathrm{S}_{\mathrm{AD}}(\mathrm{M}, \mathrm{Int})$ & States of region & I & $\mathrm{Y}$ & $\mathrm{Y}$ & $1-C, n-C$ & $\mathrm{Y}$ & Ds-BC & $\begin{array}{l}\mathrm{Cc} / \\
\mathrm{Cw}\end{array}$ & $\mathrm{N}$ \\
\hline 13 & M & $\mathrm{S}_{\mathrm{AD}}(\mathrm{M}$, Int $)$ & States of region & I & $\mathrm{N}$ & $\mathrm{Y}$ & $1-\mathrm{C}, \mathrm{n}-\mathrm{C}$ & $\mathrm{N}$ & - & $\mathrm{Cw}$ & $\mathrm{Y}$ \\
\hline 14 & M, Q & $\begin{array}{l}\mathrm{S}_{\mathrm{AD}}(\mathrm{M}, \mathrm{Int}), \\
\mathrm{S}_{\mathrm{AC}}(\mathrm{M}, \mathrm{Isogr}), \\
\mathrm{S}_{\mathrm{F}}(\mathrm{M}, \text { Diagr }), \\
\mathrm{S}_{\mathrm{L}}(\mathrm{M}, \text { Diagr }), \\
\mathrm{S}_{\mathrm{L}}(\mathrm{Q}), \mathrm{S}_{\mathrm{AD}}(\mathrm{Q})\end{array}$ & $\begin{array}{l}\text { States of world, } \\
\text { phenomenon extent }\end{array}$ & $\mathrm{C}, \mathrm{K}$ & $\mathrm{N}$ & $\mathrm{N}$ & $1-C, D$ & $\mathrm{~N}$ & - & $\begin{array}{l}\mathrm{Cc} / \\
\mathrm{Cw}\end{array}$ & $\mathrm{Y}$ \\
\hline 15 & $\mathrm{M}, \mathrm{Q}$ & $\begin{array}{l}\mathrm{S}_{\mathrm{AC}}(\mathrm{M}, \text { Isogr }), \\
\mathrm{S}_{\mathrm{AD}}(\mathrm{Q}), \\
\mathrm{S}_{\mathrm{F}}(\mathrm{Q}, \mathrm{Top}) \\
\mathrm{S}_{\mathrm{F}}(\mathrm{M}, \text { Diagr }), \\
\mathrm{S}_{\mathrm{AD}}(\mathrm{M}, \text { Int })\end{array}$ & $\begin{array}{l}\text { States of world, } \\
\text { phenomenon extent }\end{array}$ & $\mathrm{C}, \mathrm{K}$ & $\mathrm{N}$ & $\mathrm{N}$ & $1-C, D$ & $\mathrm{~N}$ & - & $\begin{array}{l}\mathrm{Cc} / \\
\mathrm{Cw}\end{array}$ & $\mathrm{Y}$ \\
\hline 16 & M & $\mathrm{S}_{\mathrm{AD}}(\mathrm{M}, \mathrm{Int})$ & $\begin{array}{l}\text { States and its lower } \\
\text { administrative units }\end{array}$ & I & $\mathrm{Y}$ & $\mathrm{N}$ & 1-C, n-C & $\mathrm{Y}$ & Ic & $\mathrm{Cc}$ & $\mathrm{Y}$ \\
\hline 17 & M & $\mathrm{S}_{\mathrm{AD}}(\mathrm{M}$, Int $)$ & NUTS & I & $\mathrm{N}$ & $\mathrm{Y}$ & $\mathrm{D}$ & $\mathrm{N}$ & - & $\mathrm{Cc}$ & $\mathrm{N}$ \\
\hline 18 & M & $\mathrm{S}_{\mathrm{AD}}(\mathrm{M}$, Int $)$ & States of region & I & $\mathrm{N}$ & $\mathrm{N}$ & $n-C$ & $\mathrm{~N}$ & - & $\mathrm{Cc}$ & $\mathrm{N}$ \\
\hline 19 & $\mathrm{M}, \mathrm{Q}$ & $\begin{array}{l}\mathrm{S}_{\mathrm{AD}}(\mathrm{M}, \text { Int }) \\
\mathrm{S}_{\mathrm{AD}}(\mathrm{Q}), \\
\mathrm{S}_{\mathrm{F}}(\mathrm{Q}, \mathrm{Top}), \\
\mathrm{S}_{\mathrm{F}}(\mathrm{M}, \text { Diagr }) \\
\end{array}$ & NUTS, States of region & I & $\mathrm{N}$ & $\mathrm{N}$ & $1-\mathrm{C}$ & $\mathrm{N}$ & - & $\mathrm{Cc}$ & $\mathrm{Y}$ \\
\hline 20 & Q & $\begin{array}{l}\mathrm{S}_{\mathrm{F}}(\mathrm{Q}, \mathrm{Top}) \\
\mathrm{S}_{\mathrm{AD}}(\mathrm{Q})\end{array}$ & Slovakia & - & - & $\mathrm{N}$ & $\mathrm{D}$ & $\mathrm{N}$ & - & $\mathrm{Cc}$ & $\mathrm{Y}$ \\
\hline 21 & M & $\mathrm{S}_{\mathrm{AD}}(\mathrm{M}, \mathrm{Int})$ & $\begin{array}{l}\text { Slovakia and its lower } \\
\text { administrative units }\end{array}$ & LV & $\mathrm{N}$ & $\mathrm{N}$ & $1-\mathrm{C}, \mathrm{D}$ & $\mathrm{N}$ & - & $\mathrm{Cc}$ & $\mathrm{Y}$ \\
\hline
\end{tabular}

A - type of presented data (Q - qualitative, M - quantitative), B - map syntactic types, C - spatial extent and level of detail, $\mathrm{D}$ - type of data scale (I - intervals, LV - intervals with limit values, $\mathrm{C}$ - continuous, $\mathrm{K}$ - categories), $\mathrm{E}$ - possibility of data scale change ( $\mathrm{Y}$ - yes, $\mathrm{N}$ - no), $\mathrm{F}$ - data series ( $\mathrm{Y}$ - yes, $\mathrm{N}$ - no), $\mathrm{G}$ - colour schemes (1-C - 1 colour scheme, n-C - sequence of multiple colours, D - different colours), $\mathrm{H}$ - the possibility of colour scheme change (Y - yes, N - no), I - change in colour scheme (Ic - individual colours, Ds - default schemes, Ds-BC - default schemes in Brewer colours, (-) - no change possible), J - quality of default colour scheme or colours $(\mathrm{Cc} / \mathrm{Cw}$ - cartographically correct/wrong), $\mathrm{K}$ - colour schemes varied by themes $(\mathrm{Y}-$ yes, $\mathrm{N}-$ no)

- J - quality of default colour scheme or colours cartographically correct/wrong,

- K - colour schemes varied by themes - yes/no.

Table 2 shows that the clear majority of the displayed data are quantitative data, which has an impact on choice of the map representation method. Qualitative data were displayed only in two cases, and four WMAs displayed both qualitative and quantitative data. We have recognized use of seven different map types. The most abundant method is $\mathrm{S}_{\mathrm{AD}}(\mathrm{M}, \mathrm{Int})$, followed by $S_{A D}(Q)$ and $S_{F}(M$, Diagr). The method $\mathrm{S}_{\mathrm{AD}}(\mathrm{M}, \mathrm{Int})$ is used for quantitative data. To represent qualitative data, tree methods $-\mathrm{S}_{\mathrm{AD}}(\mathrm{Q}), \mathrm{S}_{\mathrm{L}}(\mathrm{Q})$ and $\mathrm{S}_{\mathrm{F}}(\mathrm{Q}$, Top) - were used. WMAs (no. 14, 15 and 19) displaying both types of data applied four to five different methods. The number of map representation methods depends also on the diversity of themes.

WMAs displayed different areas, from states of the world, through states of selected regions to only one state. In some WMAs, data were further downscaled to administrative units, e.g. NUTS. The last two WMAs display data for the area of Slovakia. The most frequently used type of data scale was scale with intervals. Two WMAs used two scales, continuous and categorical. In one case, we identified the intervals with limit values and categories. The default colour scheme was used in the majority of WMAs with appropriate colour sequence of either shades of one colour or appropriate colour sequence of two to three colours. Some WMAs have also colour schemes made from various colours. Possibility to change data scale (the classification method) as well as colour scheme was possible in the majority of WMAs under the head of WHO, with default colour schemes designed by Brewer (2014). Data series was used in 10 analysed WMAs. Possibility to make changes in colour schemes of displayed data was available in half of the analysed WMAs, mostly varying between Brewer colour schemes (Brewer 2014). It was possible to change individual colours in the scheme in two cases. The quality of default colour 
scheme or colours is a subjective criterion; we evaluated 14 WMAs as cartographically correct, 4 as cartographically wrong, and 3 WMAs reached mixed results - some schemes were correct from cartographic point of view, other were wrong. Half of the analysed WMAs differentiated colour schemes for different thematic areas.

\section{Our solution: cartographical aspects of WMA for environmental health}

\subsection{Technical background of styling}

The presented WMA, available at https://uvp.geonika. sk/map/ (Department of Cartography... 2016), was created with the aim to combine and visualize spatial data related to the issue of environmental health in Slovakia from various sources. It was programmed in Javascript using the OpenLayers library with Apache as web server and GeoServer as map server. Data are stored in the PostgreSQL/PostGIS database system. The overall layout of the application is described elsewhere (Benová, Feciskanin 2014), the technical details of the application will be published once the development is finished. Here we will focus on the technical and cartographical details of data styling.

Only shortly regarding the technical background of data visualization; the application enables interactive display of published map layers, which user can switch on and off in the layer tree. User can move in a map window, zoom in and out, change the orientation of the map between geographical north and the orientation of the S-JTSK coordinate system, change the order of layers, set their transparency, and get information about objects using object identification tool. All these functions support and expand the visualization of data by conventional map styling, which is the focus of the presented paper.

The application uses GeoServer as a map server. It is an open-source map server with user-friendly user interface, which enables comfortable publication of maps in online environment. To style and accordingly render geospatial data, of both vector and raster type, GeoServer uses Styled Layer Descriptor (SLD) markup language, one of the standards defined by the Open Geospatial Consortium (2015), which were developed with the aim to enable interoperability of web solutions for geospatial data. SLD language is based on the XML schema, thus its elements are defined by XML tags. They are used to define metadata of the SLD style as well as rules for rendering the data.

NamedLayer tag is the base of the SLD style XML file. It contains tags that define the name of the styled layer and its styles. Each UserStyle tag can contain name, title and abstract to describe the style. Within FeatureTypeStyle tag it is possible to define different rules for rendering features. Each rule can contain name and title and has to contain symbolizer, which is the part defining the way data render. Within rule data can be filtered using ogc:Filter tag and some of the filter expressions (Open Source Geospatial Foundation 2015a) and rendering can be limited by zoom levels.

The tag name for the symbolizer depends on the type of the features to be rendered (PointSymbolizer for figural signs, LineSymbolizer for linear signs, PolygonSymbolizer for areal signs, TextSymbolizer for text labels or RasterSymbolizer for raster data). Subtags of each symbolizer type differ (some subtags are shared, though), which is given by varying requirements for rendering of various data types. In all cases, sizes are specified in pixels (although it can be specified in ground units using a GeoServer SLD extension) and RGB colours in a hexadecimal format (i.e. \#RRGGBB). Full definition of SLD tags can be found in the GeoServer documentation (Open Source Geospatial Foundation 2015b).

In GeoServer, each published WMS layer has to have associated at least one SLD file. Defining more SLD files is possible, with one being set as a default style. This possibility was used in case of publishing time series and parameters separately for men and women in the WMA (for more details see below). The SLD styles were directly used to generate legend for the data, so no additional work was required in this regard.

\subsection{Data content of the WMA}

Data published in the WMA (overall 355 layers) are organized into five thematic groups and 30 subgroups (Table 3). As a base layer, users can opt for WMTS layer of ZBGIS data provided by Geodesy, Cartography and Cadastre Authority of Slovak Republic or a digital orthophotomap with labels. Moreover, for better orientation users can add data from the first thematic group containing layers of administrative borders and nomenclature. The other four thematic groups represent data on demography, environmental and health indicators, and results of the 2011 Census.

Demographic data are available at the level of regions, districts and municipalities, and for years 2007 or 2008 to 2013. Health indicators are aggregated at the same administrative units; however, the time frame of the data varies. Most of environmental indicators have their own geometry, except for emissions, which 
Table 3. Thematic groups and subgroups of data layers in the presented web mapping application for environmental health

\begin{tabular}{|c|c|}
\hline Group & Subgroup \\
\hline Topology & Administrative borders \\
\hline \multirow{5}{*}{ Demography } & Nomenclature \\
\hline & Deaths \\
\hline & Births \\
\hline & Abortions \\
\hline & Population density \\
\hline \multirow{18}{*}{$\begin{array}{l}\text { Environmental } \\
\text { indicators }\end{array}$} & Terrain \\
\hline & Geomorphological division \\
\hline & Geology \\
\hline & Land cover \\
\hline & Air quality $\mathrm{NO}_{2}$ \\
\hline & Air quality $\mathrm{O}_{3}$ \\
\hline & Air quality $\mathrm{PM}_{10}$ \\
\hline & Air quality $\mathrm{PM}_{2.5}$ \\
\hline & Air quality $\mathrm{SO}_{2}$ \\
\hline & Air quality index \\
\hline & Emissions $\mathrm{NO}_{\mathrm{x}}$ \\
\hline & Emissions CO \\
\hline & Emissions $\mathrm{SO}_{2}$ \\
\hline & Emissions PM \\
\hline & Environmental and health risk \\
\hline & Chemical elements in groundwater \\
\hline & Chemical elements in soils \\
\hline & Water \\
\hline \multirow{4}{*}{ Health indicators } & Acute coronary syndrome \\
\hline & Strokes \\
\hline & Birth defects \\
\hline & Infectious diseases \\
\hline \multirow{2}{*}{ Census 2011} & Flats \\
\hline & Houses \\
\hline
\end{tabular}

Table 4. Syntactic types of map representation used in the presented web mapping application

\begin{tabular}{|l|l|c|}
\hline \multicolumn{2}{|c|}{ Syntactic type or subtype } & $\begin{array}{c}\text { No. of } \\
\text { layers }\end{array}$ \\
\hline $\mathrm{S}($ Sat $)$ & aerial image use & 1 \\
\hline $\mathrm{S}_{\mathrm{F}}$ (M,Diagr) & quantitative diagrammatic sign & 4 \\
\hline $\mathrm{S}_{\mathrm{L}}(\mathrm{Q})$ & type of quantitative linear signs & 8 \\
\hline $\mathrm{S}_{\mathrm{AD}}(\mathrm{Q})$ & qualitative discrete areas & 45 \\
\hline $\mathrm{S}_{\mathrm{AD}}($ M,Int $)$ & $\begin{array}{l}\text { quantitative discrete areas } \\
\text { (choropleth type) }\end{array}$ & 160 \\
\hline $\mathrm{S}_{\mathrm{AD}}($ M,Diagr) & $\begin{array}{l}\text { quantitative discrete areas with } \\
\text { diagrams }\end{array}$ & 4 \\
\hline $\mathrm{S}_{\mathrm{AC}}$ (M,Isogr) & $\begin{array}{l}\text { quantitative continuous } \\
\text { (isogradational) areas }\end{array}$ & 130 \\
\hline $\mathrm{S}_{(\text {Georelief })}$ & georelief (terrain) representation & 3 \\
\hline
\end{tabular}

are data aggregated at the level of regions and districts, and water, which are data on quality of drinking and bathing water collected at the level of municipalities. Time frames of these data also vary. Results of the 2011 Census are presented at the level of municipalities as well as basic settlement units.

\subsection{Map syntactic types in the WMA and styling approaches}

Based on the classification of map representation methods by Pravda $(2003,2006)$ and Pravda and Kusendová (2007) we identified and styled 8 syntactic types of map representation (Table 4), of which quantitative discrete areas (choropleth type) and quantitative continuous isogradational areas (isarithmic type) were most prevalent.

Considering creation of the SLD styles, the syntactic types required different approaches. For S(Sat) type a default GeoServer raster SLD style was used, which is designed to display RGB values in the raster file in a traditional way and is thus suitable for imageries.

$S_{F}(M$, Diagr) type is a map with figural map signs localized as points, used in the map application to represent geological samples categorized by age. In the SLD file figural map signs are styled using PointSymbolizer tag. Basic shapes, as those we applied (rotated square and triangle) and their appearance are defined within Graphic tag. Basic shape and colour of fill and stroke (which is optional) are defined within Mark tag, size and rotation (if required) within separate respective tags. Apart from the basic shapes of figural signs (circle, square, triangle, star, cross, $\mathrm{x}$ ) users can use external graphical files (in .png or .svg file format), so the options of styling are basically endless.

To represent borders (administrative and geomorphological), $S_{L}(Q)$ type was applied. The data were either lines or polygons, but in both cases the Stroke tag was defined for its visualization.

$\mathrm{S}_{\mathrm{AD}}(\mathrm{Q})$ type representing visualization of qualitative discrete areas was applied for six datasets, including geomorphological division, tectonic map, land cover data, and water quality. Because we distinguish several quantitative data categories within one dataset, filters needed to be applied in the SLD style. Since only one filter and one respective symbolizer can be defined in a rule, every category was assigned with one rule. In case of $\mathrm{S}_{\mathrm{AD}}(\mathrm{Q})$ type, setting a filter is straightforward action of assigning respective value to the required attribute inside PropertyIsEqualTo tag. The style is then defined inside PolygonSymbolizer tag. 
$\mathrm{S}_{\mathrm{AD}}(\mathrm{M}, \mathrm{Int})$, also known as choropleth type, is the most frequently used syntactic type in the presented WMA. This is a result of the fact that many data are numeric values of an attribute collected or aggregated at the level of administrative units and then normalized by the size of either population or area (demography data, emissions, health indicators, census data). The values for the respective units were categorized into intervals (more on that see below). The interval boundaries were used in filters, which in this case were compiled from two conditions using logical operation of AND. The appearance of the respective category was again defined in the PolygonSymbolizer tag. Definition of stroke colour is identical for all administrative units (\#5E5E5E), stroke size (width) differs based on the hierarchical level of the units.

It is also possible to visualize $S_{A D}(M$, Diagr) type or diagram map using SLD file. In the WMA, we needed to visualize relative proportions of selected groups of causes of death (neoplasms, diseases of circulatory system, diseases of respiratory system, diseases of digestive system, external causes of mortality, other causes) in selected years.

Visualization with diagram is enabled by an external graphic within PointSymbolizer tag. It is a chart extension using version of the (deprecated) Google Chart API called Eastwood Charts (GeoSolutions 2013). Inside the OnlineResource tag chart type (cht), chart data (chd), chart background fill (chf), chart colours (chco) and chart rotation (chp) are set. $p 3$ chart type represents flat 3D pie chart (Fig. 1), chart data specify attributes (in our case already calculated percentages) to be displayed in the diagram in the required order, chf defines solid (s) white (FFFFFF) transparent (00) background of the chart, chco defines colour of the diagram in the order respective to the order of attributes, chp defines rotation of the chart in radians, 4.71 is equivalent to $270^{\circ}$ so the chart drawing starts at 12:00 (default is 3:00). Size of the diagram is defined within a separate tag Size. We defined the size to be linearly dependant on the overall number of deaths in the administrative units.

The diagram is placed into the centroid of the respective administrative unit. We did not fill the administrative units because any other information for the units can be displayed below the diagram from the layers available in the layer tree.

Styling $\mathrm{S}_{\mathrm{AC}}(\mathrm{M}$,Isogr) map type was approached similarly as $\mathrm{S}_{\mathrm{AD}}(\mathrm{Q})$ and $\mathrm{S}_{\mathrm{AD}}(\mathrm{M}, \mathrm{Int})$ syntactic type. These data (air quality, chemical elements in groundwater and soils) were originally in raster continuous

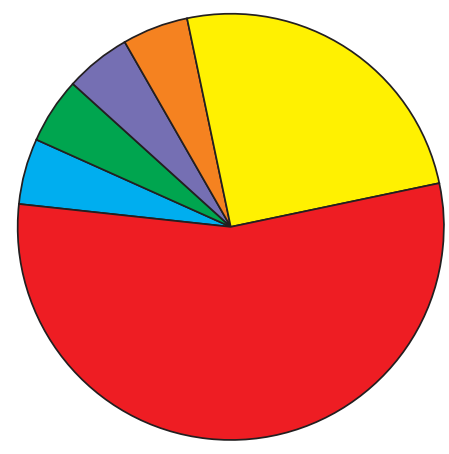

Fig. 1. 3D flat pie chart defined by SLD style

form but were reclassified into several categories (often considering the threshold value given by the national legislation) and then vectorised in order to be more easily stored in a spatial database and visualized in the WMA. Based on the categorization and required visualization either simple or combined filter was used. Again, PolygonSymbolizer tag was used for specification of the data appearance. Stroke colour in this case was identical with the respective polygon fill.

For the S(Georelief) type, i.e. georelief (terrain) representation, we applied three various subtypes: numeric - S(Georelief, Num), contour - S(Georelief, Isohyps) and hypsometric - S(Georelief, Hyps). The numeric subtype is applied within the nomenclature over the orthophotomap; selected hills are labelled with their name and elevation. The contour and hypsometric visualizations of terrain can be found in the thematic subgroup Terrain within Environmental indicators. Contours are labelled; in order to achieve the correct orientation of the labels, the contours had to be generated with consistent orientation and vendor option forcing left to right orientation of the labels had to be disabled. Some other vendor options, including label grouping and following line, were used to ensure the labels are drawn correctly. For hypsometric map we applied the combined principle of the colour scheme (Pravda, Kusendová 2007), starting from darker hues going through lighter back to darker for the highest elevations, with changes every 100 meters.

\subsubsection{Data intervals and colour schemes}

Another aspect needed to consider was selection of colour schemes and definition of classes for relevant data. For qualitative data (e.g. land cover, geomorphological division, tectonic map) we used qualitative colour schemes. To style Corine Land Cover data predefined scheme (EEA 2013) was used. For geomorphological division of the Slovak republic the colour scheme was based on the scheme of its authors (Mazúr, Lukniš 
1978). For quantitative data, we approached the selection of colours exploiting the fact that data were grouped into thematic groups and subgroups (Table 5). The colour schemes were either inspired by the ColorBrewer website (Brewer 2014) or designed by the authors.

Table 5. Applied colour schemes for thematic groups of data in the presented web mapping application

\begin{tabular}{|l|l|}
\hline \multicolumn{1}{|c|}{ Thematic group } & \multicolumn{1}{c|}{ Colour scheme } \\
\hline Demography & single hue: violet \\
\hline Infectious diseases & multi-hued: yellow to red \\
\hline Other diseases & multi-hued: yellow to orange \\
\hline Census 2011 & single hue: blue \\
\hline Emissions & single hue: turquoise \\
\hline Air quality index & multi-hued: green-yellow-orange \\
\hline Air quality & multi-hued: yellow-green-blue \\
\hline $\begin{array}{l}\text { Elements in groundwater } \\
\text { and soils }\end{array}$ & $\begin{array}{l}\text { multi-hued: yellow to red to } \\
\text { violet }\end{array}$ \\
\hline
\end{tabular}

Number of intervals varied between 3 (for choropleth maps of 8 Slovak regions) to 11 (air quality $\mathrm{SO}_{2}$ ). In case of choropleth mapping $\left(\mathrm{S}_{\mathrm{AD}}(\mathrm{M}, \mathrm{Int})\right.$ type), number of intervals depended on number of regions, range and distribution of data and where applicable (in case of time series) spatiotemporal data variability (e.g. for a single map of 8 Slovak regions 4 intervals would be excessive (generally three intervals were created), with an exception of a time series with high temporal variability, as in case of distribution of whooping cough or scarlet fever in the regions, where 5 and 4 intervals, respectively, were created). For data where no data value was present, separate interval was created and filled with grey colour (\#CCCCCC). If there was a high frequency of zero values (mostly in case of municipalities, but also some cases of districts), separate interval for zero values was created, and filled with white colour. For $\mathrm{S}_{\mathrm{AC}}(\mathrm{M}, \mathrm{Isogr})$ number of intervals depended on data variability mostly.

\begin{tabular}{cc}
\hline ČISTOTA OVZDUŠIA $O_{3}(10)$ & $\mathbf{T}$ \\
\hline Priemerná ročná koncentrácia $\mathrm{O}_{3} 2004$ & $\mathbf{i}$ \\
\hline Priemerná ročná koncentrácia $\mathrm{O}_{3} 2005$ & $\mathbf{i}$ \\
\hline Priemerná ročná koncentrácia $\mathrm{O}_{3} 2006$ & $\mathbf{i}$ \\
\hline Priemerná ročná koncentrácia $\mathrm{O}_{3} 2007$ & $\mathbf{i}$ \\
\hline Priemerná ročná koncentrácia $\mathrm{O}_{3} 2008$ & $\mathbf{i}$ \\
\hline Priemerná ročná koncentrácia $\mathrm{O}_{3} 2009$ & $\mathbf{i}$ \\
\hline Priemerná ročná koncentrácia $\mathrm{O}_{3} 2010$ & $\mathbf{i}$ \\
\hline Priemerná ročná koncentrácia $\mathrm{O}_{3} 2011$ & $\mathbf{i}$ \\
\hline Priemerná ročná koncentrácia $\mathrm{O}_{3} 2012$ & $\mathbf{i}$
\end{tabular}

Fig. 2. Time series of $\mathrm{S}_{\mathrm{AC}}$ (M,Isogr) data as available in the layer tree of the presented web mapping application: one layer per one year
Intervals were limited by minimum and maximum values of data or data series. Their boundaries were determined by various methods depending on the data nature, including quantiles, natural breaks (Jenks) and manual settings. For dataset of elements in groundwater and soils, values of limit and recommended concentration levels, where applicable, were incorporated into the interval boundaries. To enhance the visual communication of these values, obvious change in colour was applied at such boundaries.

\subsubsection{Data series}

Data for which time series were available were visualized in annual resolution. The way of displaying the times series differs depending on the syntactic map type. $S_{A C}(M$,Isogr) time series data (air quality data) differ in geometry, therefore each year is stored as one layer, published in GeoServer, referred to SLD style and made available in the layer tree within respective thematic subgroup (Fig. 2). The style is same for all years, since it is only geometry changing, intervals remain the same.

For choropleth maps $\left(\mathrm{S}_{\mathrm{AD}}(\mathrm{M}, \mathrm{Int})\right)$ geometry does not change over time, it is the value of attributes, which changes. Thus, there is no need to have separate layers for the annual data, all can be stored in one attribute table under different attribute names. In this way one layer is published in GeoServer with one default SLD style (for average values of the available time span). SLD styles for annual data can be then added as additional styles. This way of manipulating SLD styles enables selection of year in a dropdown menu (Fig. 3), where data are ordered from the latest to the oldest with the average at the top. The ordering is based on the alphabetic order of the codes that GeoServer automatically generates for each SLD file. Due to a bug in the software, however, the order had to be adjusted manually.

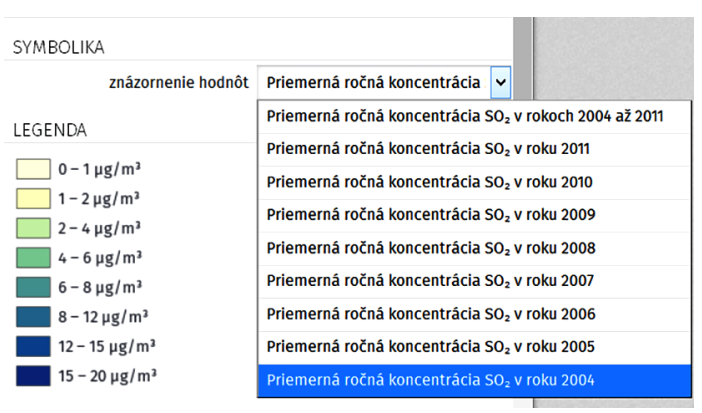

Fig. 3. Time series of $\mathrm{S}_{\mathrm{AD}}(\mathrm{M}, \mathrm{Int})$ data as available in the dropdown menu with available styles for the selected layer: one style per one year and average 
Again, for better comparison of data between years, based on the literature review by Brewer and Pickle (2002), intervals for all years are designed to be the same and boundaries to be rounded numbers. This approach facilitates easier understanding of absolute differences and changes in time and is suitable for users of the WMA from the general public who are lacking cartographic education.

The same approach was applied for styling of gender data series. Selected data are visualized separately by sex (i.e. men, women, and together).

\subsubsection{Labels}

Text labels are styled using TextSymbolizer tag. In the presented WMA, several label layers were created, one as a part of the orthophotomap, labelling towns and villages, mountain summits (name and elevation), water bodies and geomorphological units (Fig. 4), one as a separate nomenclature layer in the thematic group of Topology and other labelling geomorphological division and terrain contours. For all labels, we used FiraSans font, an open-source sans-serif font, because it is free, web-friendly and available in 16 weights, enabling big styling variability.

\section{Conclusions}

The presented WMA represents a complex solution for visualization of a wide range of spatial data from the field of environmental health at one place with the aim to facilitate easier comprehension of the complicated relations between human health and environment. The application should serve to a wide audience consisting of various professionals as well as general public. Therefore, close attention was paid to data styling so the data visualization is as clear and unambiguous as possible. In the paper we presented and compared styling approaches for several syntactic map types using Open Geospatial Consortium SLD standard, which is a standard styling technique of GeoServer. SLD schema with its extensions proved to be suitable and sufficient approach for styling of various syntactic map types. Moreover, the application functionality, such as zooming, transparency setting, identification and others, support the data visualization and make the use of data easier and friendlier.

However, there are several limitations of our data styling in the WMA, with regard to styling in general rather than SLD styling. Issue, which is most pronounced for health and demographic data and municipality level of territorial units, is rate reliability. Many

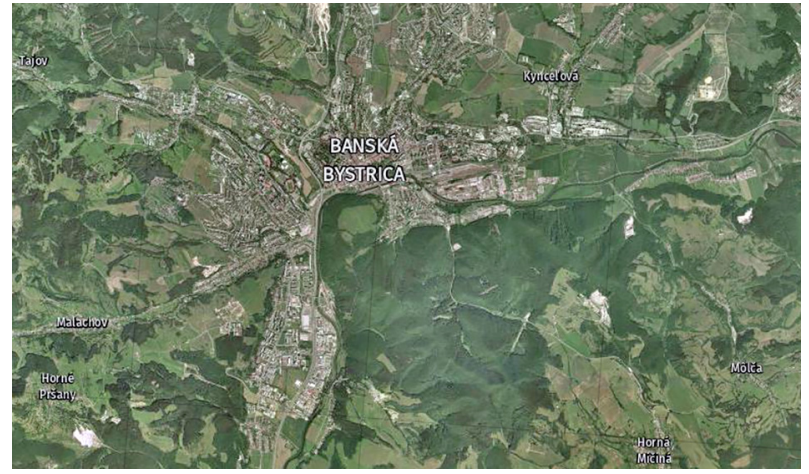

Fig. 4. Example of labels above the orthophotomap

municipalities in Slovakia have very few inhabitants (while others have many) and in such cases even with one occurrence of the event rates might be artificially high and unreliable. The reliability could be visualized (in a separate layer or even within the same layer), however, due to really high number of layers that needed to be styled (around 300), this was not manageable by now.

Another improvement that would help users understand the data are animations for time series. Currently, time series visualization is operated in two ways: either by separate layers for available years (when geometry of data changes) or by changing the style of a layer (when geometry does not change, such as for data at the level of administrative units). This obviously does not represent the most appropriate way of time series visualization because it requires excessive user interaction that is not necessary with animations. Nevertheless, time series visualization is not the main objective of the WMA and therefore animations are not available.

To conclude, we have built a complex web mapping system for visualization and basic spatial analysis of environmental, demographic and health data at one place available to professionals as well as general public. Styling the huge amount of data to effectively communicate their content to audiences that are not cartographically educated was challenging and timeconsuming. Despite our efforts, there are still challenges remaining due to the complexity of the task.

\section{Funding}

This publication is the result of the project implementation: Comenius University Science Park -2 . phase ITMS 2014+ 313021D075 supported by the Research \& Innovation Operational Programme funded by the European Regional Development Fund. 


\section{References}

Avraam, M. 2009. Geoweb, web mapping and web GIS [online], [cited 03 December 2014]. Available from Internet: http:// michalisavraam.org/2009/03/geoweb-web-mapping-andweb-gis/

Bell, B. S.; Hoskins, R. E.; Pickle, L. W.; Wartenberg, D. 2006. Current practices in spatial analysis of cancer data: mapping health statistics to inform policymakers and the public, International Journal of Health Geographics 5(49).

Benová, A.; Feciskanin, R. 2014. Hodnotenie webových mapových aplikácií so zameraním na environmentálne zdravie a riziká z hladiska ich kompozície a funkčnosti, Acta Geographica Universitatis Comenianae 58(2): 193-227.

Brewer, C. A. 2014. ColorBrewer: color advice for maps [online], [cited 19 November 2014]. Available from Internet: http:// colorbrewer2.org/

Brewer, C. A.; Pickle, L. 2002. Evaluation of methods for classifying epidemiological data on choropleth maps in series, Annals of Association of American Geographers 92(4): 662681. https://doi.org/10.1111/1467-8306.00310

Department of Cartography, Geoinformatics and Remote Sensing, Faculty of Natural Science, Comenius University in Bratislava. 2016. Mapový portál projektu Enviro-medicína pre 21. storočie - geografický info-systém a environmentálne $z$ dravie [online], [cited 18 January 2017]. Available from Internet: https://uvp.geonika.sk/map/

EEA. 2013. Corine Land Cover 2006 seamless vector data [online], [cited 19 June 2015]. European Environmental Agency. Available from Internet: http://www.eea.europa.eu/dataand-maps/data/clc-2006-vector-data-version-3\#tab-additional-information

GeoSolutions. 2013. Charting [online], [cited 18 June 2015]. GeoServer Training. Available from Internet: http://geoserver.geo-solutions.it/edu/en/pretty_maps/charting.html

Hallisey, E. J. 2005. Cartographic visualization: an assessment and epistemological review, The Professional Geographer 57(3): 350-364.

https://doi.org/10.1111/j.0033-0124.2005.00483.x

Mazúr, E.; Lukniš, M. 1978. Regionálne geomorfologické členenie SSR, Geografický časopis 30(2): 101-125.

Open Geospatial Consortium. 2015. Styled layer descriptor [online], [cited 22 June 2015]. Available from Internet: http:// www.opengeospatial.org/standards/sld

Open Source Geospatial Foundation. 2015a. Filters - GeoServer 2.8.x user manual [online], [cited 23 June 2015]. Available from Internet: http://docs.geoserver.org/latest/en/user/styling/sld-reference/filters.html

Open Source Geospatial Foundation. 2015b. SLD reference GeoServer 2.8.x user manual [online], [cited 23 June 2015]. Available from Internet: http://docs.geoserver.org/latest/en/ user/styling/sld-reference/index.html

Pravda, J. 2003. Mapový jazyk. Bratislava: Univerzita Komenského v Bratislave.

Pravda, J. 2006. Metódy mapového vyjadrovania. Klasifikácia a ukážky. Bratislava: VEDA, vydavatel'stvo SAV.

Pravda, J. 2002. The methods of map representation as a map syntactic types, in E-mail seminar of cartography. The cartographic education \& theoretical or connected with the cartographic practice, 2001-2002, University of Architecture, Civil Engineering and Geodesy, Sofia, Bulgaria.
Pravda, J.; Kusendová, D. 2007. Aplikovaná kartografia. Bratislava: Geo-grafika.

Roth, R. E. 2013. Cartographic interaction: what we know and what we need to know, Journal of Spatial Information Science 6(6): 59-115.

Smith, D. A. 2016. Online interactive thematic mapping: applications and techniques for socio-economic research, Computers, Environment and Urban Systems 57: 106-117. https:// doi.org/10.1016/j.compenvurbsys.2016.01.002

Zastrow, M. 2015. Science on the map, Nature 519: 119-120. https://doi.org/10.1038/519119a

Tatiana HARCINÍKOVÁ is a PhD candidate at the Department of Cartography, Geoinformatics and Remote Sensing, Faculty of Natural Sciences, Comenius University in Bratislava and a researcher at the Comenius University Science Park in Bratislava, Slovakia. Her research interests include cartographic visualization, spatial analyses and spatial modelling of environmental and health data.

Alexandra BENOVÁ, $\mathrm{PhD}$ is a researcher at the Department of Cartography, Geoinformatics and Remote Sensing, Faculty of Natural Sciences, Comenius University in Bratislava and at the Comenius University Science Park in Bratislava, Slovakia. Her research interests include map language, thematic cartography, old maps, cartographic visualization, and geomorphometry.

Richard FECISKANIN, $\mathrm{PhD}$ is a researcher at the Department of Cartography, Geoinformatics and Remote Sensing, Faculty of Natural Sciences, Comenius University in Bratislava and at the Comenius University Science Park in Bratislava, Slovakia. His research interests: mapping information services and standards; web programming and developing web map applications; digital cartography and cartographic modelling.

Radoslav CHUDÝ, PhD is a researcher at the Comenius University Science Park in Bratislava, Slovakia. His research interests include geoinformatics, spatial data harmonization, and implementation of the Directive 2007/2/EC (INSPIRE).

Miroslav KOŽUCH, PhD is a researcher at the Department of Cartography, Geoinformatics and Remote Sensing, Faculty of Natural Sciences, Comenius University in Bratislava and at the Comenius University Science Park in Bratislava, Slovakia. His research work is concerned with aerial image processing with digital photogrammetry methods into the form of digital orthophotomaps including automatic procedures of digital aerial image processing - digital aerotriangulation using automatic image matching, discrete altitude point field collection using digital image correlation, and evaluation of the obtained results.

Vladimír PELECH is a PhD candidate at the Department of Cartography, Geoinformatics and Remote Sensing, Faculty of Natural Sciences, Comenius University in Bratislava and a researcher at the Comenius University Science Park in Bratislava, Slovakia. Focus of his research is spatial relationship of selected essential elements in groundwater and cardiovascular diseases. Topic of his dissertation is Methods and tools for modelling geographic information sources for monitoring environmental health. 
Tomáš SCHMIDT is a PhD candidate at the Department of Cartography, Geoinformatics and Remote Sensing, Faculty of Natural Sciences, Comenius University in Bratislava and a researcher at the Comenius University Science Park in Bratislava, Slovakia. His areas of interest include database systems, spatial database systems, data analysis, geographical information systems, and web programming.

Hana STANKOVÁ, PhD is a researcher at the Department of Cartography, Geoinformatics and Remote Sensing, Faculty of Natural Sciences, Comenius University in Bratislava and at the Comenius University Science Park in Bratislava, Slovakia. Her main research areas of interests include remote sensing data interpretation, object based image analysis, land cover mapping/ change detection and environmental health.
Juraj VALIŠ, PhD is a researcher at the Department of Cartography, Geoinformatics and Remote Sensing, Faculty of Natural Sciences, Comenius University in Bratislava and at the Comenius University Science Park in Bratislava, Slovakia. His research focuses on geoinformatics, geodesy, real estate cadastre, spatial data harmonization, and implementation of the Directive 2007/2/EC (INSPIRE).

Eva MIČIETOVÁ, Dr Assoc. Prof., PhD is a head of the Department of Cartography, Geoinformatics and Remote Sensing, Faculty of Natural Sciences, Comenius University in Bratislava, Slovakia, and scientific coordinator of activity 2.5 - Enviromedicine for the 21st century - Geographical Information System and Environmental Health of the project University Science Park, ITMS: 26240220086. Her professional specialization includes geoinformatics, geographical databases, spatial modelling of environmental health. 